\title{
$255 \mathrm{~nm}$ LED kills Enterococcus faecalis and induces the production of cellular biomarkers in HEPM cells and gingival fibroblasts
}

\author{
Kimberly Morio, DDS, MS ${ }^{1}$, Emma L. Thayer², Amber M. Bates, PhD $^{3}$, Kim A. Brogden, \\ $\mathrm{PhD}^{2,4,{ }^{*}}$ \\ ${ }^{1}$ Department of Endodontics, College of Dentistry, The University of lowa, lowa City, IA 52242, \\ USA
}

${ }^{2}$ lowa Institute for Oral Health Research, College of Dentistry, The University of lowa, lowa City, IA 52242, USA

${ }^{3}$ Department of Human Oncology, University of Wisconsin School of Medicine and Public Health, University of Wisconsin-Madison, Madison, WI 53705 USA

${ }^{4}$ Department of Periodontics, College of Dentistry, The University of lowa, lowa City, IA 52242 , USA

\section{Abstract}

Introduction: Successful treatment of infected or inflamed endodontic tissues requires chemomechanical debridement of the canal spaces and proper sealing of the coronal and apical canal openings. Only a few methods are available to further disinfect areas or initiate regeneration of local tissues. In this study, we assessed the ability of $255 \mathrm{~nm}$ and $405 \mathrm{~nm}$ light emitting diode (LED) treatment to kill planktonic cultures of Enterococcus faecalis (E. faecalis) and induce the production of cellular biomarkers related to endodontic tissue regeneration.

Methods: We determined the antimicrobial effects of $255 \mathrm{~nm}$ and $405 \mathrm{~nm}$ LED treatment on $E$. faecalis and the effects of $255 \mathrm{~nm}$ and $405 \mathrm{~nm}$ LED treatment on the production of osteoinductive, angiogenic, proliferative, and proinflammatory biomarkers from human embryonic palatal mesenchyme (HEPM) cells and gingival fibroblasts.

Results: We demonstrated that 1) $255 \mathrm{~nm}$ LED, but not $405 \mathrm{~nm}$ LED, treatment killed $E$. faecalis, 2) $255 \mathrm{~nm}$ LED and sodium hypochlorite ( $\mathrm{NaOCl})$ more efficiently killed $E$. faecalis, 3) neither $255 \mathrm{~nm}$ nor $405 \mathrm{~nm}$ LED treatment affected the viability of HEPM cells and gingival fibroblasts, and 4) $255 \mathrm{~nm}$ LED treatment, alone or in combination with $405 \mathrm{~nm}$ LED treatment, of HEPM cells and gingival fibroblasts induced the production of biomarkers related to endodontic tissue regeneration.

Conclusions: The results in this study suggest a new treatment modality using short periods of $255 \mathrm{~nm}$ LED treatment as an adjunct to chemo-mechanical debridement for the disinfection of inflamed sites and the production of biomarkers related to endodontic tissue regeneration.

*Corresponding author: kim-brogden@uiowa.edu. 


\section{Keywords}

255 nm LED; 405 nm LED; Enterococcus faecalis; HEPM cells; primary human gingival fibroblasts; regeneration

\section{Introduction}

Successful treatment of infected or inflamed endodontic tissues is dependent upon i) bacterial disinfection of the root-canal system to prevent re-infection, and ii) chemical irrigation to disinfect, dissolve, and remove necrotic debris from the canal wall and spaces. The instrumentation of the canal space is a vital step in these processes, but it has its limitations due to the complexity of the lateral canals, fins, and crevices along the walls of the canal systems. This has been demonstrated by microcomputed tomography (CT) scanning which showed extensive root canal configuration (1) and large areas of the root canals walls that were left untouched by the instruments (2-5).

Light based technologies involving ultraviolet C (UVC, 200-280 nm) and blue light (400$450 \mathrm{~nm}$ ) therapies offer attractive approaches as an adjunct to chemo-mechanical debridement for controlling microbial infections with beneficial impacts on local tissues (69). Both UVC and blue light are antimicrobial with relatively minor effects to host tissues compared to their high antimicrobial activity to microbial pathogens $(8,10)$. Equally attractive is the reported ability of laser irradiation to increase proliferation of mesenchymal cells, increase proliferation and mineralization of dental pulp constructs, increase cell proliferation and bone sialoprotein expression in dental pulp stem cells (DPSCs), and induce the production of TGF- $\beta 1$, which is involved in differentiation of DPSCs (9).

Enterococcus faecalis (E. faecalis) induces persistent infections and is often associated with multi-species microbial biofilms in root canal infections and endodontic disease (11-14). In this study, we first assessed the ability of $255 \mathrm{~nm}$ and $405 \mathrm{~nm}$ LED to kill planktonic cultures of $E$. faecalis growing on exponential phase. We then assessed the effect of $255 \mathrm{~nm}$ and $405 \mathrm{~nm}$ LED on the viability of human embryonic palatal mesenchyme (HEPM) cells and gingival fibroblasts and the ability of $255 \mathrm{~nm}$ and $405 \mathrm{~nm}$ LED (in combination) on HEPM cells and gingival fibroblasts to induce the production of osteoinductive, angiogenic, proliferative, and proinflammatory biomarkers.

\section{Materials and Methods}

\section{Microorganism and Culture Conditions}

E. faecalis was obtained from the American Type Culture Collection (ATCC 29212, ATCC, Manassas, VA). E. faecalis was cultivated in BBL trypticase soy broth (Becton, Dickinson and Company, Sparks, MD) with $0.6 \%$ yeast extract (Janssen Pharmaceuticalaan, Geel, Belgium) and on trypticase soy broth, yeast extract (TSBYE) containing Difco 1.5\% agar (Becton, Dickinson and Company) at $37^{\circ} \mathrm{C}$. Three-hour bacterial cultures were adjusted in TSBYE broth to an optical density of 0.108 at $600 \mathrm{~nm}$ (Spectronic 20D1, Thermo Fisher Scientific, Inc., Waltham, MA). Plate counts determined that these cultures contained 4.5$5.9 \times 10^{7}$ colony forming units $(\mathrm{CFU})$ of $E$. faecalis $/ \mathrm{mL}$. 
For surface killing assays, a sterile swab was dipped into the adjusted culture (0.108 OD, $600 \mathrm{~nm}$ ) and streaked onto a TSBYE agar plate to create a 'bacterial lawn' of confluent growth.

To determine the kinetics of antimicrobial activity, the adjusted culture $(0.108 \mathrm{OD}, 600 \mathrm{~nm})$ was diluted $10^{-3}$-fold to contain $\sim 10^{5} \mathrm{CFU} / \mathrm{mL}$. $7.0 \mathrm{~mm}$ discs were punched from sterile cellulose nitrate filter membranes (7182-002 plain cellulose nitrate filter membrane, $0.2 \mu \mathrm{m}$, Whatman International Ltd., Maidstone, UK) and placed on TSBYE agar plates. $5 \mu \mathrm{L}$ of microbial culture was added to each disc and incubated for 30 minutes. The 30 minute incubation time allowed the broth to be absorbed by the underlying agar medium leaving the E. faecalis on top of the membrane.

To determine the synergistic effects of $255 \mathrm{~nm}$ LED and sodium hypochlorite ( $\mathrm{NaOCl})$ treatments, the adjusted culture $(0.108 \mathrm{OD}, 600 \mathrm{~nm})$ was diluted $10^{-2}$-fold to contain $\sim 10^{6}$ $\mathrm{CFU} / \mathrm{mL}$.

\section{Cell Lines and Culture Conditions}

Human embryonic palatal mesenchyme (HEPM) cells are pre-osteoblast cells and were obtained from the American Type Culture Collection (CRL-1486, ATCC, Manassas, VA). These cells are responsive (15) and have been used to i) study epigenetic regulation of osteogenesis and bone regeneration (16); evaluate craniofacial palatal closure (17); and study osteoblast growth, adhesion, spreading patterns, and differentiation (18-20). HEPM cells were cultivated in Dulbecco's Modified Eagle Medium, (DMEM, Gibco by Life Sciences, Life Technologies Corp., Carlsbad, CA). DMEM complete medium contained 1.0 $\mathrm{g} / \mathrm{L}$ D-glucose, L-glutamine, $110 \mathrm{mg} / \mathrm{L}$ sodium pyruvate, $10.0 \%$ fetal bovine serum (No. 302020, ATCC, Manassas, VA), and 1\% penicillin-streptomycin (No. 15140-122, PenicillinStreptomycin, 10,000 U/mL, Gibco by Life Sciences, Life Technologies Corp.). The identity of the HEPM cell line was authenticated by genetic profiling of their polymorphic short tandem repeat (STR) loci (STR Profiling Cell Authentication Service, ATCC, Manassas, VA) as described by Capes-Davis et al.(21). Eight STR loci (TH01, TPOX, vWA, CSF1PO, D16S539, D7S820, D13S317 and D5S818) were examined for cell line authentication, and amelogenin was examined for gender identification and human cell line authentication. The STR profile results for the HEPM cell line used in this study were identical to the STR profile for the ATCC HEPM cell line.

Primary human gingival fibroblasts were also used and obtained from the American Type Culture Collection (PCS-201-018, ATCC, Manassas, VA). Gingival fibroblasts were cultivated in Fibroblast Basal Medium (ATCC PCS-201-030, ATCC, Manassas, VA) with the added fibroblast growth kit (PCS-201-041, ATCC, Manassas, VA) containing $0.5 \mathrm{ml} / \mathrm{L}$ rh FGF $\beta(5 \mathrm{ng} / \mathrm{mL}) ; 18.75 \mathrm{ml} / \mathrm{L}$ L-glutamine $(7.5 \mathrm{mM}) ; 0.5 \mathrm{ml} / \mathrm{L}$ ascorbic acid $(50 \mu \mathrm{g} / \mathrm{mL})$; $0.5 \mathrm{ml} / \mathrm{L}$ hydrocortisone hemisuccinate $(1 \mu \mathrm{g} / \mathrm{mL}) ; 0.5 \mathrm{ml} / \mathrm{L}$ recombinant human insulin $(5$ $\mu \mathrm{g} / \mathrm{mL}$ ) and $10.0 \%$ fetal bovine serum (No. 30-2020, ATCC, Manassas, VA). These were primary cells and thus could not be authenticated.

Both HEPM cells and gingival fibroblasts were cultivated in T75 flasks (30641U, Corning, Inc., Corning, $\mathrm{NY}$ ) at $37^{\circ} \mathrm{C}$ in a humidified incubator with $5.0 \% \mathrm{CO}_{2}$. At $\sim 70-80 \%$ 
confluent growth, cells were detached with $0.25 \%$ trypsin- $0.53 \mathrm{mM}$ EDTA solution (ATCC, Manassas, VA), washed in their respective media, counted, and adjusted to contain $1.0 \times 10^{5}$ viable cells $/ \mathrm{mL}$. $200 \mu \mathrm{L}$ aliquots were removed and put into 96-well microtiter plates (Costar 3596, Corning, Inc., Corning, NY). The plates were incubated for 16 hours in a humidified incubator at $37^{\circ} \mathrm{C}$ with $5.0 \% \mathrm{CO}_{2}$.

\section{$255 \mathrm{~nm}$ and $405 \mathrm{~nm}$ LEDs and Setup}

$255 \mathrm{~nm}$ and $405 \mathrm{~nm}$ LEDs were obtained from Thorlabs (Newton, NJ). Energy doses were determined using UVC meter ( $255 \mathrm{~nm}$, Solarmeter Model 8.0, Glenside, PA) and PM400 Optical Power Meter (405 nm, Thorlabs, Newton, NJ). The energy dose was calculated as the $\mathrm{mW} \times$ time (s). For 30 seconds, the amount of energy delivered to the $3.0 \mathrm{~mm}$ circle at the end of the canula (Fig. 1) was $9.28 \mathrm{~J}$ dose (255 nm LED) and $17.88 \mathrm{~J}$ dose (405 nm LED).

LEDs were put into 3-dimensional printed holders (Fig. 1), which served as a heat sink to prevent both LED and sample from heating during LED treatment. The LEDs were supported by clamps hooked to a ring stand above a scissors jack. An aluminum canula was placed into the LED source to direct LED light on to agar plates containing the cultures of $E$. faecalis and into the tissue culture wells of the 96-well plate containing HEPM cells and gingival fibroblasts.

\section{LED Treatment of $E$. faecalis}

To assess the effects of $255 \mathrm{~nm}$ and $405 \mathrm{~nm}$ LED treatments on $E$. faecalis viability, TSBYE agar plates were swabbed with $E$. faecalis and treated with $255 \mathrm{~nm}$ LED or $405 \mathrm{~nm}$ LED for 0, 30, 60, and 90 seconds (Fig. $1 A$ ). After treatment, the plates were incubated for 16 hours at $37^{\circ} \mathrm{C}$ and examined for areas void of microbial growth (Fig. $1 B$ ). The surface of membrane discs containing $E$. faecalis were treated with $255 \mathrm{~nm}$ LED or $405 \mathrm{~nm}$ LED for 0, 30, 60, and 90 seconds (Fig. 1C). The discs were then removed from the agar surface, placed in $1.0 \mathrm{ml}$ TSBYE broth, and mixed. $50 \mu \mathrm{l}$ of each broth culture was put onto TSBYE agar plates in triplicate. Plates were incubated at $37^{\circ} \mathrm{C}$ for 16 hours. Colonies per spot were counted, multiplied by 20 to get $\mathrm{CFU} / \mathrm{mL}$, and the percent killing was determined by comparing the concentrations of each treatment time point to the non-treatment time point control (Fig. 1D).

\section{LED and $\mathrm{NaOCI}$ Treatment of E. faecalis}

To assess the synergistic effects of $255 \mathrm{~nm}$ LED and $\mathrm{NaOCl}$ treatments on E. faecalis viability, $10 \mu \mathrm{l}$ of a $10^{-2}$ bacterial dilution was put into holes ( $3 \mathrm{~mm}$ dia.) punched in blood agar plates containing trypticase soy agar with 5\% defibrinated sheep blood (Remel, Lenexa, KS) and incubated for 30 minutes to allow absorption of the culture media into the agar leaving E. faecalis on the walls of the wells. Each well was then administered a different treatment. One well was filled with $10 \mu \mathrm{l}$ of distilled water and served as the untreated control. A second well was treated for 30 seconds with $255 \mathrm{~nm}$ LED. A third well was treated with $10 \mu \mathrm{l}$ of $1 \% \mathrm{NaOCl}$ solution for 60 seconds. A fourth well was treated for 30 seconds with $255 \mathrm{~nm}$ LED and then 60 seconds with $10 \mu \mathrm{l} 1 \% \mathrm{NaOCl}$. A fifth well was treated for 60 seconds with $10 \mu \mathrm{l} \% \mathrm{NaOCl}$ and then for 30 seconds with $255 \mathrm{~nm}$ LED. 
After each treatment, wells were rinsed with $10 \mu \mathrm{l}$ of TSBYE broth to remove bacteria and suspended into $1.0 \mathrm{ml}$ of TSBYE broth. Each tube was mixed and $50 \mu \mathrm{l}$ was removed and spotted onto blood agar in triplicate. Plates were incubated overnight at $37^{\circ} \mathrm{C}$ with $5 \% \mathrm{CO}_{2}$ and colonies were counted the next day.

\section{HEPM Cell and Fibroblast Treatment}

To assess the effects of $255 \mathrm{~nm}$ and $405 \mathrm{~nm}$ LED treatments on HEPM cell and gingival fibroblast metabolism (e.g., the conversion of resazurin to resorufin), $180 \mu \mathrm{l}$ of tissue culture media was removed from the adherent cells. HEPM cells and gingival fibroblasts were each treated with $255 \mathrm{~nm}$ LED for 0, 30, 60, and 90 seconds. HEPM cells and gingival fibroblasts in other wells were treated with $405 \mathrm{~nm}$ LED for 0, 30, 60, and 90 seconds. In additional experiments, HEPM cells and gingival fibroblasts were exposed to $255 \mathrm{~nm}$ LED for 30 seconds, $405 \mathrm{~nm}$ LED for 30 seconds, or a combination of $255 \mathrm{~nm}$ LED for 30 seconds followed by $405 \mathrm{~nm}$ LED for 30 seconds. After treatment, $200 \mu \mathrm{l}$ of complete media with $1.0 \%$ Alamar Blue (Invitrogen corp., Carlsbad, CA) werewas added per well and the cells were incubated in a humidified incubator at $37^{\circ} \mathrm{C}$ with $5.0 \% \mathrm{CO}_{2}$. The median fluorescence intensity (MFI) for the conversion of resazurin to resorufin was measured at $0,2,4,8$, and 16 hours post-LED treatment. MFI of the metabolic reduction of resazurin to resorufin was determined using an excitation wavelength of $544 \mathrm{~nm}$ and an emission wavelength of 590 nm (SpectraMax M2e Multi-Mode Microplate Reader, Molecular Devices, LLC, Sunnyvale, $\mathrm{CA})$.

To assess the effects of $255 \mathrm{~nm}$ and $405 \mathrm{~nm}$ LED treatment on HEPM cell and fibroblast viability, $180 \mu \mathrm{l}$ of tissue culture media was removed from the adherent cells in culture. HEPM cells and fibroblasts were each treated with $255 \mathrm{~nm}$ LED for 0, 30, 60, and 90 seconds. HEPM cells and fibroblasts in other wells were treated with $405 \mathrm{~nm}$ LED for 0, 30, 60 , and 90 seconds. In additional experiments, HEPM cells and fibroblasts were exposed to $255 \mathrm{~nm}$ LED for 30 seconds, $405 \mathrm{~nm}$ LED for 30 seconds, and a combination of $255 \mathrm{~nm}$ LED for 30 seconds followed by $405 \mathrm{~nm}$ LED for 30 seconds. Immediately after treatment, $200 \mu$ of the LIVE/DEAD working solution (L3224, Life Technologies Corp., Eugene, OR), containing $2 \mu \mathrm{M}$ calcein AM and $4 \mu \mathrm{M}$ ethidium homodimer-1 (EthD-1), was added per well and the cells were photographed (Olympus CKX41 tissue culture microscope, Olympus DP70 digital camera, Melville, NY). Calcein AM is a non-fluorescent compound that is converted to a green-fluorescent calcein by intracellular esterase activity in viable cells and EthD-1 is a weakly fluorescent compound until bound to DNA in non-viable cells. The plates were incubated for 45 minutes and read in the spectrophotometer (SpectraMax M2e Multi-Mode Microplate Reader, Molecular Devices, LLC). Calcein was excited at $485 \mathrm{~nm}$ and detected at $530 \mathrm{~nm}$. EthD-1 was excited at $530 \mathrm{~nm}$ and detected at $645 \mathrm{~nm}$.

\section{Osteoinductive, Angiogenic, Proliferative, and Proinflammatory Biomarkers}

To assess the effects of $255 \mathrm{~nm}$ and $405 \mathrm{~nm}$ LED treatment on the production of osteoinductive (BMP-2, BMP-4, BMP-9, and BMP-10), angiogenic (VEGFA, PDGF-A, FGF-acidic, and PIGF), proliferative (EGF and TGFa), and proinflammatory factors (IL6, IL8, and TNFa) from HEPM cells and fibroblasts, $180 \mu$ of media was removed from the adherent cells in culture. HEPM cells and fibroblasts were each treated with $255 \mathrm{~nm}$ LED 
for 30 seconds, $405 \mathrm{~nm}$ LED for 30 seconds, and a combination of $255 \mathrm{~nm}$ LED for 30 seconds followed by $405 \mathrm{~nm}$ LED for 30 seconds. After treatment, $200 \mu \mathrm{l}$ complete media was added to the plates containing HEPM cells and fibroblasts and incubated in a humidified incubator at $37^{\circ} \mathrm{C}$ with $5.0 \% \mathrm{CO}_{2}$. Cell culture media was removed at 0,24 , and 48 hours post-LED treatment and frozen at $-80^{\circ} \mathrm{C}$ until analysis.

The concentrations of osteoinductive (BMP-2, BMP-4, BMP-9, and BMP-10), angiogenic (VEGFA, PDGF-A, FGF-acidic, and PIGF), proliferative (EGF and TGFa), and proinflammatory factors (IL6, IL8, and TNFa) in HEPM and fibroblast culture media were determined in triplicate wells using multiplex immunoassays (Luminex Human Magnetic Assay, R\&D Systems, Minneapolis, MN) read on the Luminex 100 (Luminex, Madison, WI). These immunoassay kits use antibody-coated magnetic beads to bind the desired analyte and use a standard curve of known concentrations to determine the unknown concentrations (Milliplex Analyst v5.1 software, EMD Millipore, Billerica, MA). Curves were constructed from the standards and their respective MFI readings, and values were interpolated directly on the instrument (xPonent v3.1 software, Luminex, Austin, TX) and readout files (Milliplex Analyst v5.1 software, EMD Millipore, Billerica, MA).

\section{Statistical Analysis}

The MFI values and biomarker concentrations were first transformed by adding 1.0 MFI unit or $1.0 \mathrm{pg} / \mathrm{mL}$ to each respective value. A $\log 10$-transformation was then applied. The log transformation attenuates the positive skew in the distributions of the MFI and chemokine concentrations and makes the normality assumption more defensible. One-way fixed-effect ANOVA models were fit to the log-transformed concentrations. Pairwise group comparisons were conducted using the method of Tukey's Honestly Significant Difference (HSD). A 0.05 level was used to determine statistically significant differences. In graphs, bar values with the same letter(s) were not significantly different. $(\mathrm{p}>.05)$. All analyses were conducted using JMP (Version 10.0, SAS, Cary, NC).

\section{Results}

\section{Effects of $255 \mathrm{~nm}$ and $405 \mathrm{~nm}$ LED Treatment on E. faecalis}

Two assays were used to demonstrate the killing effects of $255 \mathrm{~nm}$ and $405 \mathrm{~nm}$ LED treatment on $E$. faecalis (Fig. 1). The first assay assessed the killing effect of LED on a lawn of E. faecalis on TSBYE agar (Fig. 1A). $255 \mathrm{~nm}$ LED killed E. faecalis at 30, 60, and 90 seconds exposure, and no growth was seen in the areas of LED treatment after the treated plates were incubated overnight at $37^{\circ} \mathrm{C}$ (Fig. $1 B$ ). There was no killing of the untreated 0 second control. In contrast, $405 \mathrm{~nm}$ LED did not kill E. faecalis at 0, 30, 60, and 90 seconds exposure, and growth was seen in all areas of LED treatment after the plates were incubated overnight at $37^{\circ} \mathrm{C}$ (Fig. 1B).

To quantitate the effects of $255 \mathrm{~nm}$ and $405 \mathrm{~nm}$ LED treatment on microbial viability, $E$. faecalis was spotted onto $0.22 \mu \mathrm{m}$ discs, treated (Fig. 1C), suspended in $1.0 \mathrm{ml}$ TSBYE broth, plated onto TSBYE agar, and incubated overnight at $37^{\circ} \mathrm{C}$. $255 \mathrm{~nm}$ LED treatment significantly (p < .05) reduced E. faecalis viability at 30, 60, and 90 seconds exposure (Fig. 
$1 D$ ). There was no significant killing by $405 \mathrm{~nm}$ LED treatment at $0,30,60$, and 90 seconds exposure (Fig. 1D).

\section{Effects of $255 \mathrm{~nm}$ LED and $\mathrm{NaOCI}$ Treatment on E. faecalis}

E. faecalis remained viable in control treatments (38.1+1.6 SEM CFU, n=18) (Fig. 2). In comparison, E. faecalis treated with $255 \mathrm{~nm}$ LED had significantly less CFU $(9.8+0.7 \mathrm{SEM}$ $\mathrm{CFU}, \mathrm{n}=18, \mathrm{p}<.05$ ) and $E$. faecalis treated with $1 \% \mathrm{NaOCl}$ had significantly less $\mathrm{CFU}$ $(10.1+1.2$ SEM CFU, $\mathrm{n}=18, \mathrm{p}<.05)$. E. faecalis treated with $255 \mathrm{~nm}$ LED followed by $1 \%$ $\mathrm{NaOCl}$ also had significantly less CFU $(2.1+0.4$ SEM CFU, n=18, p < .05) and E. faecalis treated with $1 \% \mathrm{NaOCl}$ followed by $255 \mathrm{~nm}$ LED had significantly less CFU $(1.2+0.3$ SEM CFU, $\mathrm{n}=18, \mathrm{p}<.05)$.

\section{Effects of $255 \mathrm{~nm}$ and $405 \mathrm{~nm}$ LED on HEPM Cell and Gingival Fibroblast Metabolism and Viability}

To assess the effects of $255 \mathrm{~nm}$ and $405 \mathrm{~nm}$ LED treatment on cell metabolism, adhered HEPM cell and gingival fibroblast monolayers were treated with $255 \mathrm{~nm}$ or $405 \mathrm{~nm}$ LED for 0, 30, 60, and 90 seconds (Fig. 3) and cultured with tissue culture media containing resazurin. At 16 hours of incubation, there were no significant differences $(\mathrm{p}>.05)$ among the $\log 10$ transformed MFI values of resorufin for either HEPM cells (Fig. $3 A, \mathrm{C}$ ) or gingival fibroblasts (Fig. 3B,D) after $255 \mathrm{~nm}$ (Fig. 3A,B) or $405 \mathrm{~nm}$ LED treatments (Fig. 3C,D).

To assess the effects of $255 \mathrm{~nm}$ and $405 \mathrm{~nm}$ LED treatment on HEPM cell and fibroblast viability, adhered HEPM cell and fibroblast monolayers were treated with $255 \mathrm{~nm}$ or $405 \mathrm{~nm}$ LED for 0, 30, 60, and 90 seconds (Fig. 4) and incubated with LIVE/DEAD working solution. At 45 minutes of incubation, there were no significant differences ( $p>.05$ ) among the $\log 10$ transformed MFI values of HEPM cells (Fig. 4A,C) or gingival fibroblasts (Fig. $4 B, \mathrm{D})$ after $255 \mathrm{~nm}$ (Fig. 4A,B) or $405 \mathrm{~nm}$ (Fig. 4C,D) LED treatment.

\section{Effects of $255 \mathrm{~nm} / 405 \mathrm{~nm}$ Combination LED Treatment on HEPM Cell and Gingival Fibroblast Metabolism and Viability}

To assess the effects of combination LED treatment on HEPM cell and fibroblast metabolism, adhered HEPM cell and fibroblast monolayers were treated with $255 \mathrm{~nm}$ LED for 30 seconds, $405 \mathrm{~nm}$ LED for 30 seconds, and a combination of $255 \mathrm{~nm}$ LED for 30 seconds followed by $405 \mathrm{~nm}$ LED for 30 seconds (Fig. 5), and cultured with tissue culture media containing resazurin. At 16 hours of incubation, there were no significant differences ( $>$ > .05) among the $\log 10$ transformed MFI values of resorufin for either HEPM cells (Fig. $5 A, \mathrm{~B}$ ) or fibroblasts (Fig. $5 D, \mathrm{E}$ ) after combination LED treatment.

To assess the effects of combination LED treatment on HEPM cell and fibroblast viability, adhered HEPM cell and fibroblast monolayers were treated with $255 \mathrm{~nm}$ LED for 30 seconds, $405 \mathrm{~nm}$ LED for 30 seconds, and a combination of $255 \mathrm{~nm}$ LED for 30 seconds followed by $405 \mathrm{~nm}$ LED for 30 seconds and incubated with LIVE/DEAD working solution (Fig. 5). At 45 minutes of incubation, there were no significant differences ( $p>.05)$ among the $\log 10$ transformed MFI values of HEPM cells (Fig. 5C) or fibroblasts (Fig. 5F) after combination LED treatment. 


\section{Effects of $255 \mathrm{~nm} / 405 \mathrm{~nm}$ Combination LED Treatment on the Production of Cell Biomarkers}

To assess the effects of LED treatment on the production of cell biomarkers, adhered HEPM cell and gingival fibroblast monolayers were treated with $255 \mathrm{~nm}$ LED for 30 seconds, 405 $\mathrm{nm}$ LED for 30 seconds, and a combination of $255 \mathrm{~nm}$ LED for 30 seconds followed by 405 $\mathrm{nm}$ LED for 30 seconds and cell culture media was added back to each well. At 0, 24, and 48 hours post-LED treatment, media was removed and saved to assess osteoinductive, angiogenic, proliferative, and proinflammatory regenerative biomarkers. LIVE/DEAD working solution was added back to each well and cells were photographed.

At each time point, there were no differences in the morphologies of HEPM cells (Supplementary Fig. $1 A-\mathrm{D}$ ) or gingival fibroblasts (Supplementary Fig. $1 E-\mathrm{H}$ ) treated with $255 \mathrm{~nm}, 405 \mathrm{~nm}$, or $255 \mathrm{~nm} / 405 \mathrm{~nm}$ LED. There was a small drop in cell viability and the LIVE/DEAD assay revealed that the cells were still $80-90 \%$ viable (data not shown).

HEPM cell and gingival fibroblasts ( $\mathrm{n}=3$ replications per group) produced osteoinductive, angiogenic, proliferative, and proinflammatory biomarkers 0-48 hours (Table 1). Concentrations of biomarkers produced by both cell types continued to increase over time. At 48 hours, HEPM cells and gingival fibroblasts produced low concentrations of proliferative factors (1.07-2.37 pg/mL EGF and TGFa), low concentrations of osteoinductive factors (5.97-18.67 pg/mL BMP-2, BMP-4, and BMP-9), and moderate concentrations of osteoinductive factors (184.07-227.83 pg/mL BMP-10). HEPM cells and gingival fibroblasts also produced low (1.13-1.73 pg/mL TNFa), moderate (118.90-187.73 $\mathrm{pg} / \mathrm{mL}$ IL6), and high (2054.40-2382.03 pg/mL IL8) concentrations of proinflammatory factors and low (5.70-7.20 pg/mL PDGF-AB), moderate (45.03-194.80 pg/mL FGF-acidic and PIGF), and high (1744.33-3542.00 pg/mL VEGFA) concentrations of angiogenic factors.

In the first series of experiments ( $\mathrm{n}=9$ replications per group), $255 \mathrm{~nm}$ and $255 \mathrm{~nm} / 405 \mathrm{~nm}$ combination LED induced production of biomarkers at 24 hours post-LED exposure (Fig. 6 , Supplementary Table 1). There were significant differences ( $\mathrm{p}<.05)$ in IL6, IL8, and VEGFA concentrations in HEPM cell cultures at 24 hours (Fig. $6 A-\mathrm{C}$ ) and there were significant differences ( $\mathrm{p}<.05)$ in IL6, PIGF, and BMP9 concentrations in gingival fibroblast cell cultures at 24 hours (Fig. $6 G-\mathrm{I}$ ).

In the second series of experiments ( $\mathrm{n}=3$ replications per group), $255 \mathrm{~nm}$ and $255 \mathrm{~nm} / 405$ $\mathrm{nm}$ combination LED induced production of biomarkers at 0-48 hours post-LED exposure (Fig. 6, Supplementary Table 2). There were significant differences ( $\mathrm{p}<.05)$ in TNFa, IL6, VEGFA, BMP10, and PIGF concentrations at 24 hours and IL6 and BMP10 concentrations at 48 hours in HEPM cell cultures post-LED exposure. There were significant differences ( $\mathrm{p}$ $<.05)$ in TGFa concentrations at 24 hours and IL6 and FGF-acidic concentrations in gingival fibroblast cell cultures at 48 hours post-LED exposure. 


\section{Discussion}

Methods to assist in the resolution of endodontic tissue infection and inflammation after chemo-mechanical debridement of canal spaces could reduce infections, regenerate tissues, lessen pain, and improve overall patient recovery. These methods could include the use of LED treatment to assist in the sterilization of canal spaces and induce the production of biomarkers to initiate endodontic tissue regeneration. In this study, we hypothesized that 255 $\mathrm{nm}$ and $405 \mathrm{~nm}$ LED light could facilitate these processes. We demonstrated that 1) $255 \mathrm{~nm}$ LED, but not $405 \mathrm{~nm}$ LED treatment killed $E$. faecalis, 2) $255 \mathrm{~nm}$ LED and $\mathrm{NaOCl}$ more efficiently killed $E$. faecalis, 3 ) neither $255 \mathrm{~nm}$ nor $405 \mathrm{~nm}$ LED treatment affected the viability of HEPM cells and gingival fibroblasts, and 4) $255 \mathrm{~nm}$ LED treatment or 255 $\mathrm{nm} / 405 \mathrm{~nm}$ combination LED treatment of HEPM cells and gingival fibroblasts induced the production of biomarkers related to endodontic tissue regeneration.

Evidence in the recent literature suggests that UVC $(255 \mathrm{~nm})$ and blue $(400-450 \mathrm{~nm})$ wavelengths of light effectively kill many microbial species $(6,8,10,22,23)$ and viruses (10). When used at higher energy doses or for prolonged time periods, these wavelengths can also be cytotoxic to eukaryotic cells $(22,23)$. However, at lower energy levels for shorter time periods like those used in this study, these wavelengths can induce cells to release biomarkers related to tissue recovery and regeneration $(9,10)$.

$255 \mathrm{~nm}$ light has antimicrobial activity and is used in a variety of applications related to treating localized tissue infections (24-26).

$405 \mathrm{~nm}$ light has time-dependent and energy dose-dependent effects on prokaryotic and eukaryotic cells (23). $36 \mathrm{~J} / \mathrm{cm}^{2}$ is antimicrobial to prokaryotic microorganisms but not cytotoxic to eukaryotic cells (23). $54 \mathrm{~J} / \mathrm{cm}^{2}$ is cytotoxic to eukaryotic cells (23). The antimicrobial and cytotoxic mechanisms involve reactive oxygen species related to oxidative stress, $\mathrm{H}_{2} \mathrm{O}_{2}$ generation, and other ROS, all contributing to cellular damage (23). Together, this information suggests that there is increased susceptibility of prokaryotic microorganisms compared to eukaryotic cells that could lead to a treatment modality to preferentially inactivate microorganisms in infected tissues.

The potential for LED to induce the production of biomarkers related to tissue recovery and regeneration is equally novel and important. Work with low level laser irradiation has been shown to promote proliferation of mesenchymal cells (27), cardiac stem cells (27), bone marrow stem cells (28), and dental pulp stem cells (29). Low level laser irradiation also promotes bone marrow stem cell growth factor secretion (28), myogenic differentiation (28), accelerates pulp healing (9), and bone sialoprotein expression (9). Lasers can also activate TGF- $\beta 1$ in dental pulp stem cells (30).

The production of osteoinductive, angiogenic, proliferative, and proinflammatory biomarkers are important to tissue recovery and regeneration. In this study we looked at 13 biomarkers in these categories. Osteoinductive factors included the bone morphogenic proteins (BMPs) belonging to the TGF- $\beta$ superfamily of structurally related signaling proteins (31-33). There are 15 molecules (BMP-2 to BMP-14) and we selected 4 of these proteins. BMP-2 is capable of inducing bone and cartilage formation. BMP-4 is involved in 
the development and maintenance of bone and cartilage. BMP-9 (aka Growth/Differentiation Factor-2) is involved in the remodeling and maintenance of tissues and it can inhibit endothelial cell proliferation and migration. BMP-10 is structurally related to BMP-9, and both can inhibit endothelial cell proliferation and migration. For both HEPM cells and gingival fibroblasts, osteoinductive responses were minimal for BMP-2, BMP-4, and BMP-9 $(5.97-18.67 \mathrm{pg} / \mathrm{mL})$ and moderate for BMP-10 (184.07-227.83 pg/mL). Exposure of HEPM cells to $255 \mathrm{~nm}$ LED alone or $255 \mathrm{~nm} / 405$ LED produced variations in concentrations of BMP10 at 24 and 48 hours post-LED exposure (Fig. 6, Supplemental Table 1, and Supplemental Table 2).

Angiogenesis is critical to the regeneration of injured or infected dental tissue, and angiogenic and other growth factors are important to the reformation and survival of regenerated pulp. We selected 5 angiogenic factors. VEGFA is a potent growth and angiogenic cytokine. It stimulates proliferation and survival of endothelial cells and promotes angiogenesis and vascular permeability. PDGF-A is a potent mitogen for connective tissue cells, bone, and cartilage cells. FGF-acidic is a member of the Fibroblast Growth Factor superfamily. FGF-acidic regulates the development, restoration, and redistribution of tissue and serves to facilitate angiogenesis, wound healing, and chronic inflammation. PIGF is an angiogenic factor that stimulates and endothelial cell proliferation and migration. HEPM cells and gingival fibroblasts produced low concentrations of PDGFAB (5.70-7.20 pg/mL), moderate concentrations of FGF-acidic and PIGF (45.03-194.80 pg/ $\mathrm{mL}$ ), and high concentrations of VEGFA (1744.33-3542.00 pg/mL) (Table 1). Exposure of cells to $255 \mathrm{~nm}$ LED or $255 \mathrm{~nm} / 405$ combination LED produced variations in concentrations of VEGFA, PIGF, and FGF-acidic (Fig. 6, Supplemental Table 1, and Supplemental Table 2). There were no significant increases in PDGF-AB, FGF-acidic, and PIGF responses for HEPM cells and VEGF, PDGF-AB, and FGF-acidic responses for fibroblasts.

Proliferation of cells is an important and critical step to the regeneration of injured or infected dental tissues. We selected 2 cell proliferation related factors. EGF is a potent growth factor that stimulates the proliferation of various epidermal and epithelial cells and is involved in wound healing. TGFa is an EGF-related growth factor that stimulates the proliferation of a wide range of epidermal and epithelial cells. HEPM cells and fibroblasts produced low concentrations of EGF and TGFa (1.07-2.37 pg/mL). Exposure of fibroblasts to $255 \mathrm{~nm}$ or $255 \mathrm{~nm} / 405 \mathrm{~nm}$ combination LED produced elevated concentrations of TGFa at 24 hours post-LED exposure (Fig. 6, Supplemental Table 1, and Supplemental Table 2).

Proinflammatory chemokines that chemoattract and activate neutrophils will likely be produced and we selected 3 proinflammatory factors. IL6 regulates inflammatory responses and regulates bone metabolism. IL8 is a proinflammatory chemokine that chemoattracts and activates neutrophils. TNFa is a proinflammatory cytokine that plays a role in the induction of inflammation. HEPM cells and gingival fibroblasts produced low concentration of TNFa $(1.13-1.73 \mathrm{pg} / \mathrm{mL})$, moderate concentrations of IL6 (118.90-187.73 pg/mL), and high concentrations of IL8 (2054.40-2382.03 pg/mL). There were LED-induced angiogenic responses in IL6 for HEPM cells (Fig. 6) and in fibroblasts (Fig. 6), but there were no differences in IL8 and TNFa for HEPM cells and for gingival fibroblasts (Fig. 6, Supplemental Table 1, and Supplemental Table 2). Exposure of HEPM cells to $255 \mathrm{~nm}$ LED 
or $255 \mathrm{~nm} / 405$ LED produced variations in concentrations of TNFa, IL6, at 24 hours and IL6 at 48 hours post-LED exposure. Exposure of fibroblasts to $255 \mathrm{~nm}$ or $255 \mathrm{~nm} / 405 \mathrm{~nm}$ produced elevated concentrations of IL6 at 48 hours post-LED exposure.

The applications of light treatments are being proposed by a number of investigators. Asnaashari et al suggested that diode laser at $810 \mathrm{~nm}$ and photodynamic therapy (PDT) could reduce bacterial microflora in endodontic retreatment of teeth with periradicular lesions (34). PDT and diode laser at $810 \mathrm{~nm}$ were both effective methods for root canal disinfection. However, PDT is a suitable alternative for diode laser at $810 \mathrm{~nm}$, because of lower thermal risk on root dentin.

Advances in LED technology allows our concepts and methodologies to be applied in the form of a small hand-held device. We envision that this device would be self-contained and consist of a hand piece with a small flexible probe to deliver $255 \mathrm{~nm}$ LED deep into canal depths and spaces. Short 30 second treatments of low energy doses would be antimicrobial yet, minimally harmful to endodontic tissues and cells. In summary, the results in this study suggest a new treatment modality using $255 \mathrm{~nm}$ LED for the sterilization and regeneration of infected and inflamed endodontic tissues. Future laboratory studies in vitro will include assessing these methodologies and this device on multi-species microbial biofilms commonly found in endodontic infections, isolated dental pulp stem cells (DPSC) in vitro, the selective killing of endodontic microorganisms in the presence of cultured DPSC using an in-situ method of microscopy. Further clinical studies in vivo will include assessing this methodology and this device in patient trials in vivo.

\section{Supplementary Material}

Refer to Web version on PubMed Central for supplementary material.

\section{Acknowledgments}

All authors contributed equally to this study. The authors deny any conflicts of interest related to this study.

\section{References}

1. Alkaabi W, AlShwaimi E, Farooq I, et al. A micro-computed tomography study of the root canal morphology of mandibular first premolars in an Emirati population. Med Princ Pract 2017;26:11824. [PubMed: 27816983]

2. Siqueira JF Jr.. Aetiology of root canal treatment failure: why well-treated teeth can fail. Int Endod J 2001;34:1-10. [PubMed: 11307374]

3. Haapasalo M, Shen Y, Qian W, Gao Y. Irrigation in endodontics. Dent Clin North Am 2010;54:291312. [PubMed: 20433979]

4. Jaju S, Jaju PP. Newer root canal irrigants in horizon: a review. Int J Dent 2011;2011:851359. [PubMed: 22190936]

5. Giardino L, Estrela C, Generali L, et al. The in vitro effect of irrigants with low surface tension on Enterococcus faecalis. Iran Endod J 2015;10:174-8. [PubMed: 26229541]

6. Gwynne PJ, Gallagher MP. Light as a broad-spectrum antimicrobial. Front Microbiol 2018;9:119. [PubMed: 29456527]

7. Gupta A, Avci P, Dai T, et al. Ultraviolet radiation in wound care: sterilization and stimulation. Adv Wound Care (New Rochelle) 2013;2:422-37. [PubMed: 24527357] 
8. Yin R, Dai T, Avci P, et al. Light based anti-infectives: ultraviolet C irradiation, photodynamic therapy, blue light, and beyond. Curr Opin Pharmacol 2013;13:731-62. [PubMed: 24060701]

9. Dhillon H, Kaushik M, Sharma R. Regenerative endodontics-creating new horizons. J Biomed Mater Res B Appl Biomater 2016;104:676-85. [PubMed: 26699211]

10. Welch D, Buonanno M, Grilj V, et al. Far-UVC light: A new tool to control the spread of airbornemediated microbial diseases. Sci Rep 2018;8:2752. [PubMed: 29426899]

11. Wang QQ, Zhang CF, Chu CH, Zhu XF. Prevalence of Enterococcus faecalis in saliva and filled root canals of teeth associated with apical periodontitis. Int J Oral Sci 2012;4:19-23. [PubMed: 22422085]

12. Zehnder M, Guggenheim B. The mysterious appearance of enterococci in filled root canals. Int Endod J 2009;42:277-87. [PubMed: 19220511]

13. Kayaoglu G, Orstavik D. Virulence factors of Enterococcus faecalis: relationship to endodontic disease. Critical Reviews in Oral Biology \& Medicine 2004;15:308-20. [PubMed: 15470268]

14. Gajan EB, Aghazadeh M, Abashov R, et al. Microbial flora of root canals of pulpally-infected teeth: Enterococcus faecalis a prevalent species. J Dent Res Dent Clin Dent Prospects 2009;3:247. [PubMed: 23230477]

15. Bailer RT, Lazo A, Ng-Bautista CL, et al. Comparison of constitutive cytokine release in high and low histologic grade AIDS-related Kaposi's sarcoma cell strains and in sera from HIV+/KS+ and HIV+/KS- patients. J Interferon Cytokine Res 1995;15:473-83. [PubMed: 7648450]

16. Barkhordarian A, Sison J, Cayabyab R, et al. Epigenetic regulation of osteogenesis: human embryonic palatal mesenchymal cells. Bioinformation 2011;5:278-81. [PubMed: 21364834]

17. Stanford CM, Schneider G, Zaharias R, Seabold DA. Human embryonic palatal mesenchymal cells express osteoblast features, in vitro In: 81st General Session of the International Association for Dental Research. Goteborg, Sweden; 2003.

18. Greene RM, Lloyd MR, Pisano MM. Cyclic AMP-dependent protein kinase in human embryonic palate mesenchymal cells. In Vitro Cell Dev Biol 1992;28A:755-62. [PubMed: 1282915]

19. Du C, Schneider GB, Zaharias R, et al. Apatite/amelogenin coating on titanium promotes osteogenic gene expression. J Dent Res 2005;84:1070-4. [PubMed: 16246944]

20. Zaharias RS, Burnell KK, Brogden KA, Schneider GB. Implant surface microtopographies affect osteoblast cytokine expression In: ADEA/AADR/CADR Meeting. Orlando, FL; 2006.

21. Capes-Davis A, Reid YA, Kline MC, et al. Match criteria for human cell line authentication: where do we draw the line? Int J Cancer 2013;132:2510-9. [PubMed: 23136038]

22. McKenzie K, Maclean M, Grant MH, et al. The effects of $405 \mathrm{~nm}$ light on bacterial membrane integrity determined by salt and bile tolerance assays, leakage of UV-absorbing material and SYTOX green labelling. Microbiology 2016;162:1680-8. [PubMed: 27499074]

23. Ramakrishnan P, Maclean M, MacGregor SJ, et al. Cytotoxic responses to 405nm light exposure in mammalian and bacterial cells: involvement of reactive oxygen species. Toxicol In Vitro 2016;33:54-62. [PubMed: 26916085]

24. Dai T, Vrahas MS, Murray CK, Hamblin MR. Ultraviolet C irradiation: an alternative antimicrobial approach to localized infections? Expert Rev Anti Infect Ther 2012;10:185-95. [PubMed: 22339192]

25. Narita K, Asano K, Morimoto Y, et al. Disinfection and healing effects of 222-nm UVC light on methicillin-resistant Staphylococcus aureus infection in mouse wounds. J Photochem Photobiol B 2018;178:10-8. [PubMed: 29101868]

26. Dean SJ, Petty A, Swift S, et al. Efficacy and safety assessment of a novel ultraviolet C device for treating corneal bacterial infections. Clin Exp Ophthalmol 2011;39:156-63. [PubMed: 21105972]

27. Tuby H, Maltz L, Oron U. Low-level laser irradiation (LLLI) promotes proliferation of mesenchymal and cardiac stem cells in culture. Lasers Surg Med 2007;39:373-8. [PubMed: 17457844]

28. Hou JF, Zhang H, Yuan X, et al. In vitro effects of low-level laser irradiation for bone marrow mesenchymal stem cells: proliferation, growth factors secretion and myogenic differentiation. Lasers Surg Med 2008;40:726-33. [PubMed: 19065562]

29. Tabatabaei FS, Torshabi M, Nasab MM, et al. Effect of low-level diode laser on proliferation and osteogenic differentiation of dental pulp stem cells. Laser Phys 2015;25:095602. 
30. Arany PR, Cho A, Hunt TD, et al. Photoactivation of endogenous latent transforming growth factor- $\beta 1$ directs dental stem cell differentiation for regeneration. Sci Transl Med 2014;6:238ra69.

31. Chen D, Zhao M, Mundy GR. Bone morphogenetic proteins. Growth Factors 2004;22:233-41. [PubMed: 15621726]

32. Chen D, Zhao M, Harris SE, Mi Z. Signal transduction and biological functions of bone morphogenetic proteins. Front Biosci 2004;9:349-58. [PubMed: 14766372]

33. Mulloy B, Rider CC. The bone morphogenetic proteins and their antagonists. Vitam Horm 2015;99:63-90. [PubMed: 26279373]

34. Asnaashari M, Godiny M, Azari-Marhabi S, et al. Comparison of the antibacterial effect of $810 \mathrm{~nm}$ diode laser and photodynamic therapy in reducing the microbial flora of root canal in endodontic retreatment in patients with periradicular lesions. J Lasers Med Sci 2016;7:99-104. [PubMed: 27330705] 


\section{Significance}

Only a few methods are available to disinfect canals or induce the production of biomarkers related to endodontic tissue regeneration. Treatment of canals with $255 \mathrm{~nm}$ light emitting diodes (LED) has the potential to disinfect inflamed sites and induce the production of biomarkers related to endodontic tissue regeneration. 
A

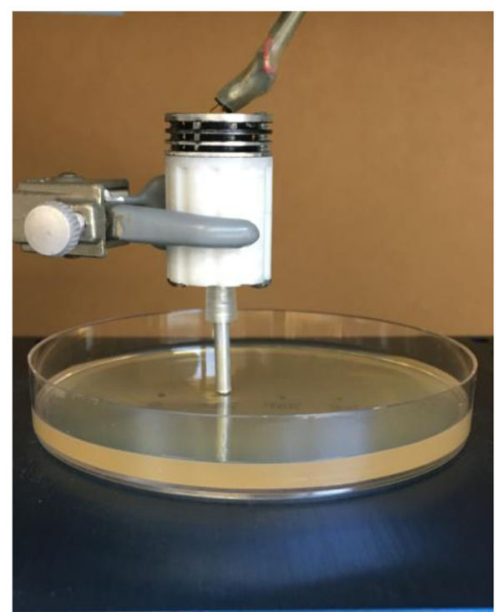

C

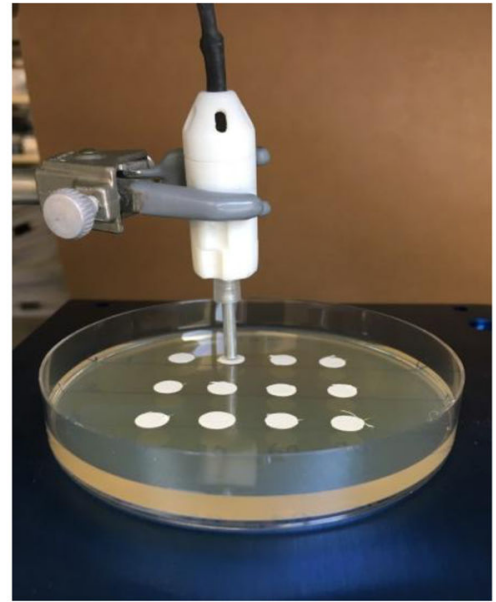

B

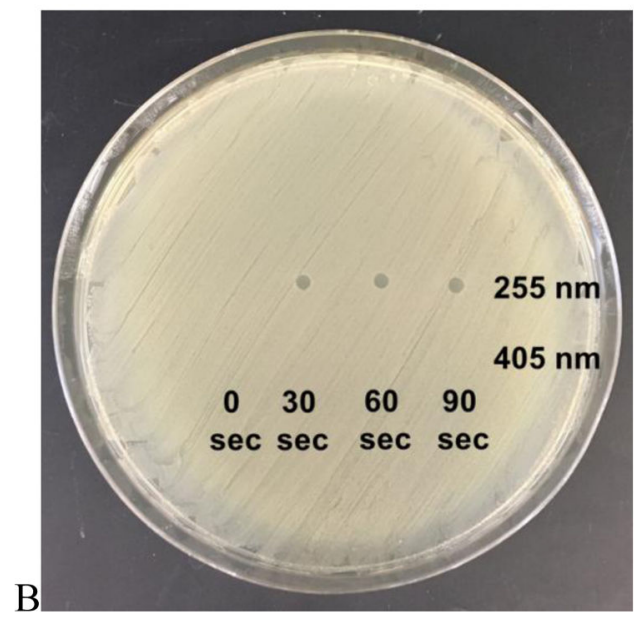

D

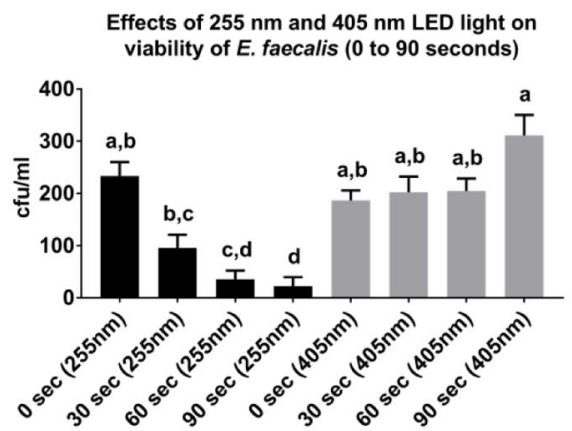

Figure 1.

The effects of $255 \mathrm{~nm}$ and $405 \mathrm{~nm}$ LED light on growth of $E$. faecalis ATCC 29212 showing $(A)$. the setup of a probe to expose $E$. faecalis streaked onto TSBYE agar and $(B)$ the killing effect of $255 \mathrm{~nm}$ LED light in this assay at 30, 60, and 90 seconds post-exposure, but no killing of $255 \mathrm{~nm}$ LED light at 0 seconds post-exposure or no killing of $405 \mathrm{~nm}$ LED light at $0,30,60$, and 90 seconds post-exposure. Quantitation of the killing effects of $255 \mathrm{~nm}$ and $405 \mathrm{~nm}$ LED light on $E$. faecalis showing $(C)$ the setup of a probe to expose $E$. faecalis spotted onto 0.22 um discs before culture and $(D)$ the killing effect of $255 \mathrm{~nm}$ LED light in this assay at 30, 60, and 90 seconds post-exposure, but no killing of $255 \mathrm{~nm}$ LED light at 0 seconds post-exposure or no killing of $405 \mathrm{~nm}$ LED light at 0, 30, 60, and 90 seconds postexposure. Bar values with the same letter(s) were not significantly different $(p>.05)$. 


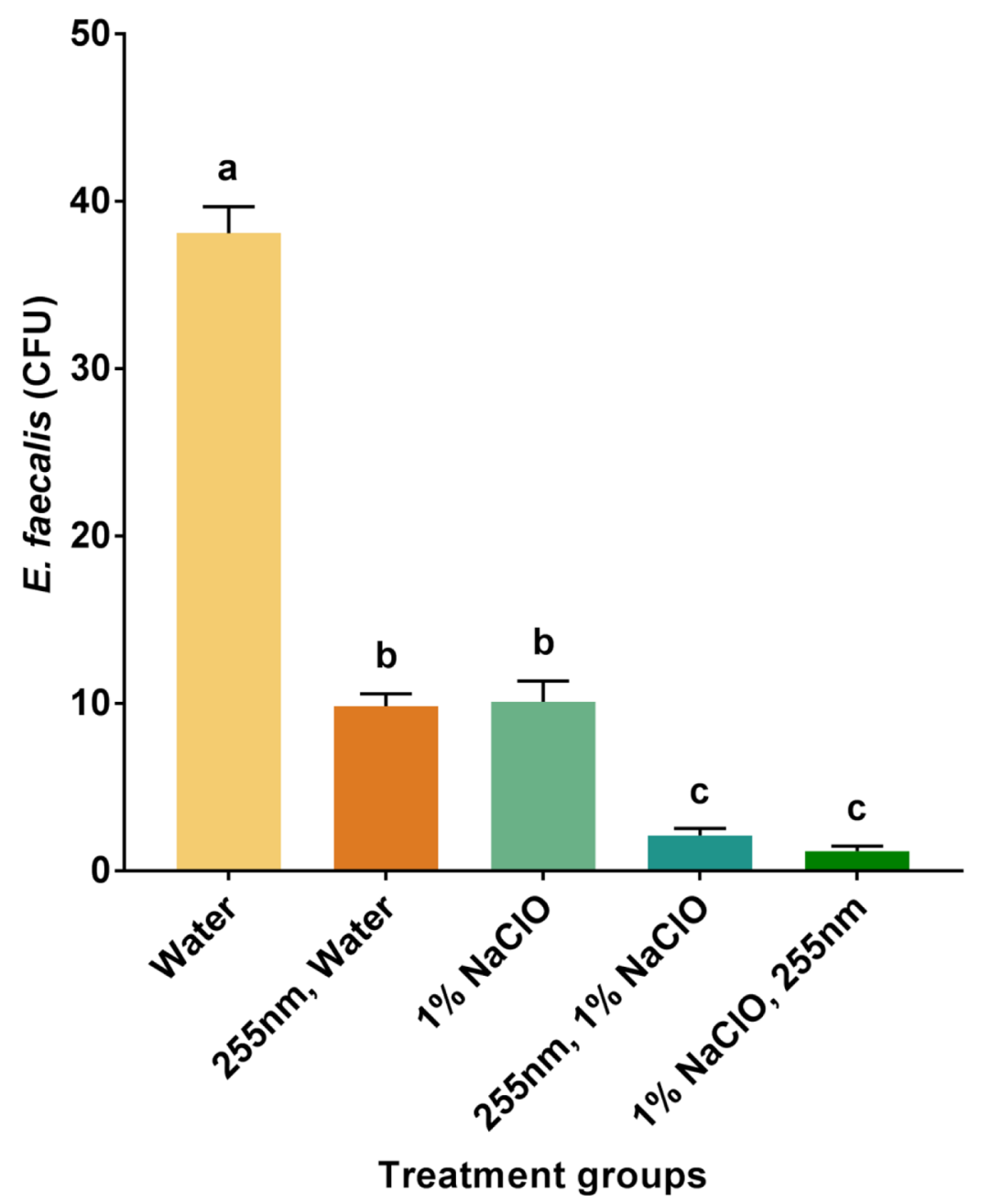

Figure 2.

Effect of $255 \mathrm{~nm} \mathrm{LED,} 1 \% \mathrm{NaOCl}$, and different combinations of $255 \mathrm{~nm}$ LED and 1\% $\mathrm{NaOCl}$ together on the growth of $E$. faecalis inside $3 \mathrm{~mm}$ wells on a blood agar plate. There were significant differences among the water control, $255 \mathrm{~nm}$ LED treatment, $1 \% \mathrm{NaOCl}$ treatment, $255 \mathrm{~nm}$ LED and $1 \% \mathrm{NaOCl}$ combination treatment, and the $1 \% \mathrm{NaOCl}$ and 255 $\mathrm{nm}$ LED combination treatment. Bar values with the same letter(s) were not significantly different $(\mathrm{p}>.05)$. 


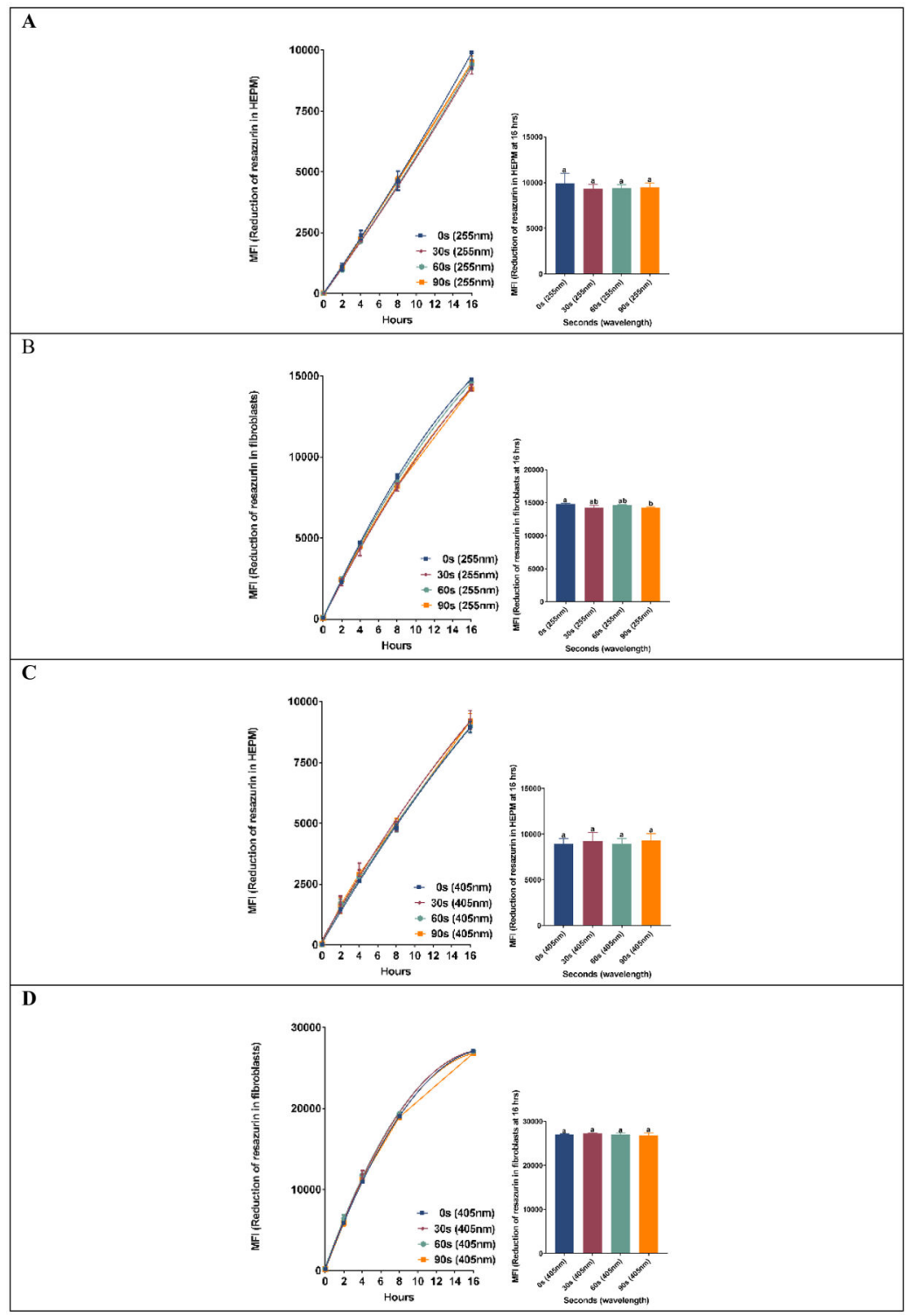

Figure 3.

Effect of $255 \mathrm{~nm}(A, B)$ and $405 \mathrm{~nm}(C, D)$ LED at $0,30,60$, and 90 seconds of treatment on the metabolic reduction of resazurin to resorufin of HEPM cells $(A, C)$ and human fibroblasts $(B, D)$ at $0,2,4,8$, and 16 hours of incubation. There were no significant differences (p $>$.05) among the $\log 10$ transformed MFI values of HEPM cells or fibroblasts at 16 hours of incubation after $255 \mathrm{~nm}$ or $405 \mathrm{~nm}$ LED treatment (inserts). Bar values with the same letter(s) were not significantly different $(\mathrm{p}>.05)$. 


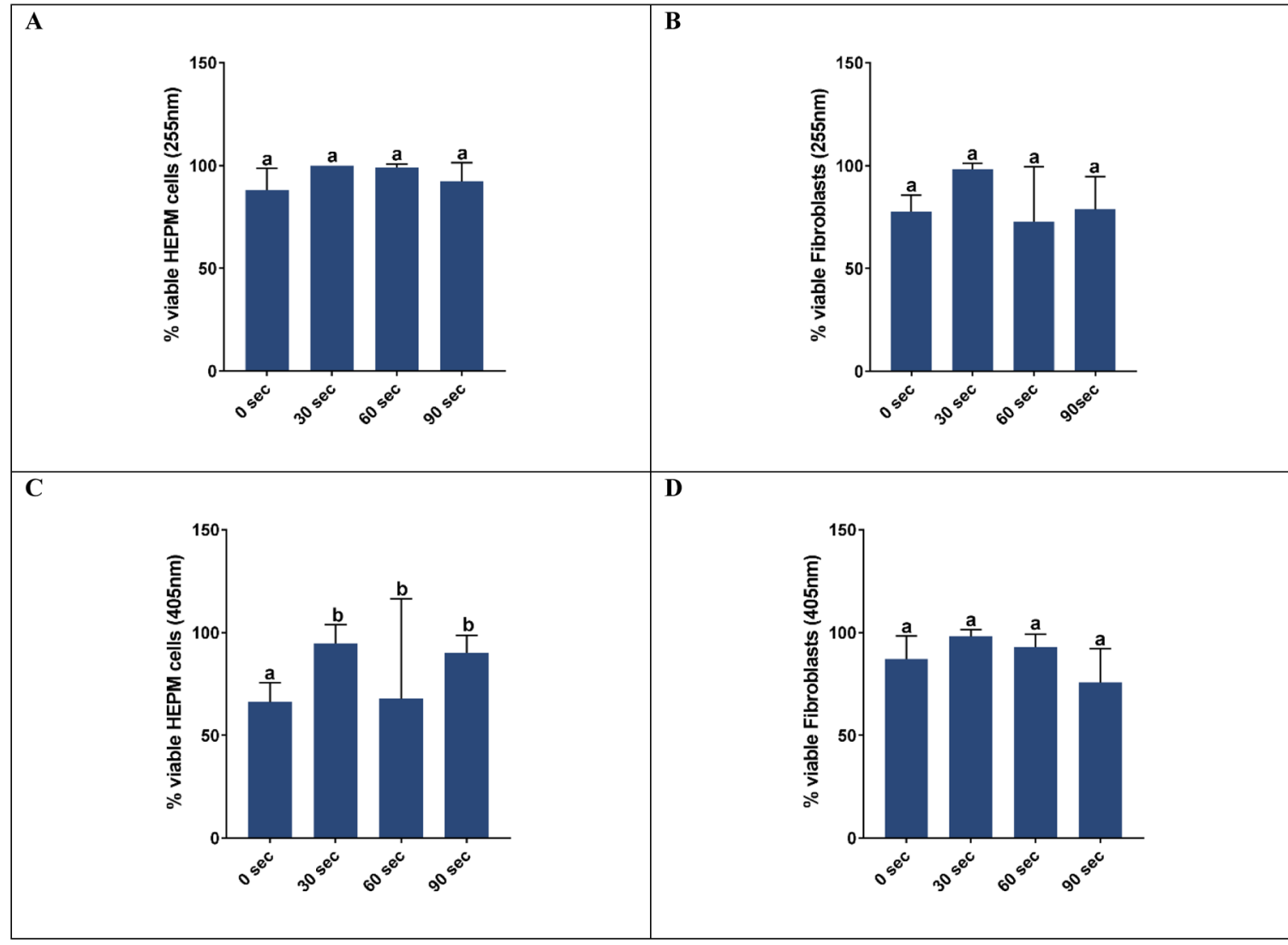

Figure 4.

Effect of $255 \mathrm{~nm}(A, B)$ and $405 \mathrm{~nm}(C, D)$ LED at 0, 30, 60, and 90 seconds of treatment on the viability of HEPM cells $(A, C)$ and human fibroblasts $(B, D)$ using $2 \mu \mathrm{M}$ calcein AM (LIVE/DEAD assay, Life Technologies Corp., Eugene, OR). There were no significant differences $(p>.05)$ among the log 10 transformed MFI values. Bar values with the same letter(s) were not significantly different $(\mathrm{p}>.05)$. 


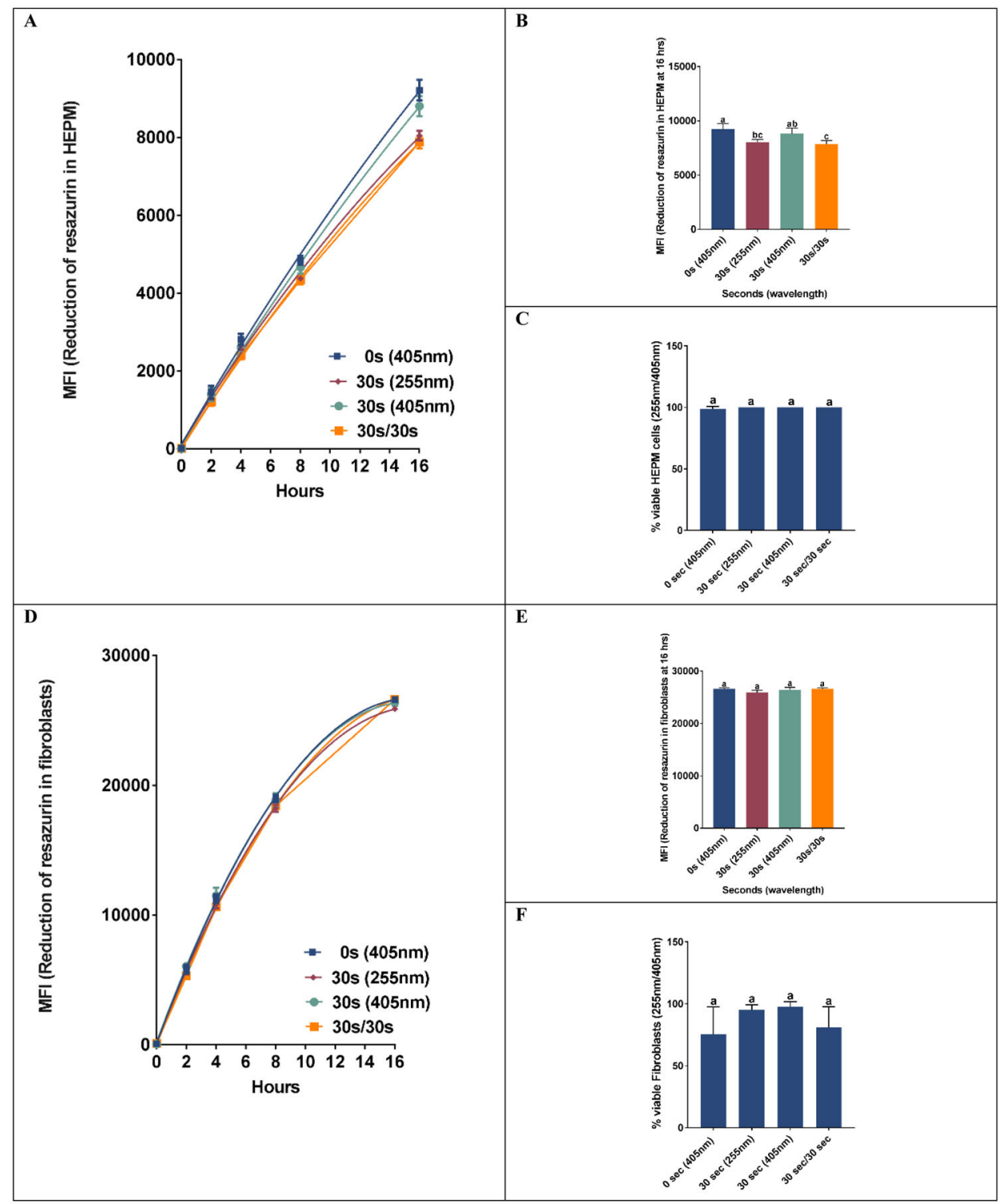

Figure 5.

Effect of $255 \mathrm{~nm}$ and $405 \mathrm{~nm}$ LED light on the metabolism $(A-D)$ and viability $(E, F)$ of HEPM cells $(A, C, E)$ and gingival fibroblasts $(B, D, F)$ at $0 \mathrm{sec}(255,405 \mathrm{~nm}$ controls), $30 \mathrm{sec}$ (255 nm alone), $30 \mathrm{sec}(405 \mathrm{~nm}$ alone), and $30 \mathrm{sec}(255 \mathrm{~nm}) / 30 \mathrm{sec}(405 \mathrm{~nm})$. The 16 hour metabolism $(C, D)$ and viability $(E, F)$ of HEPM cells and gingival fibroblasts are shown. Bar values with the same letter(s) were not significantly different $(\mathrm{p}>.05)$. 


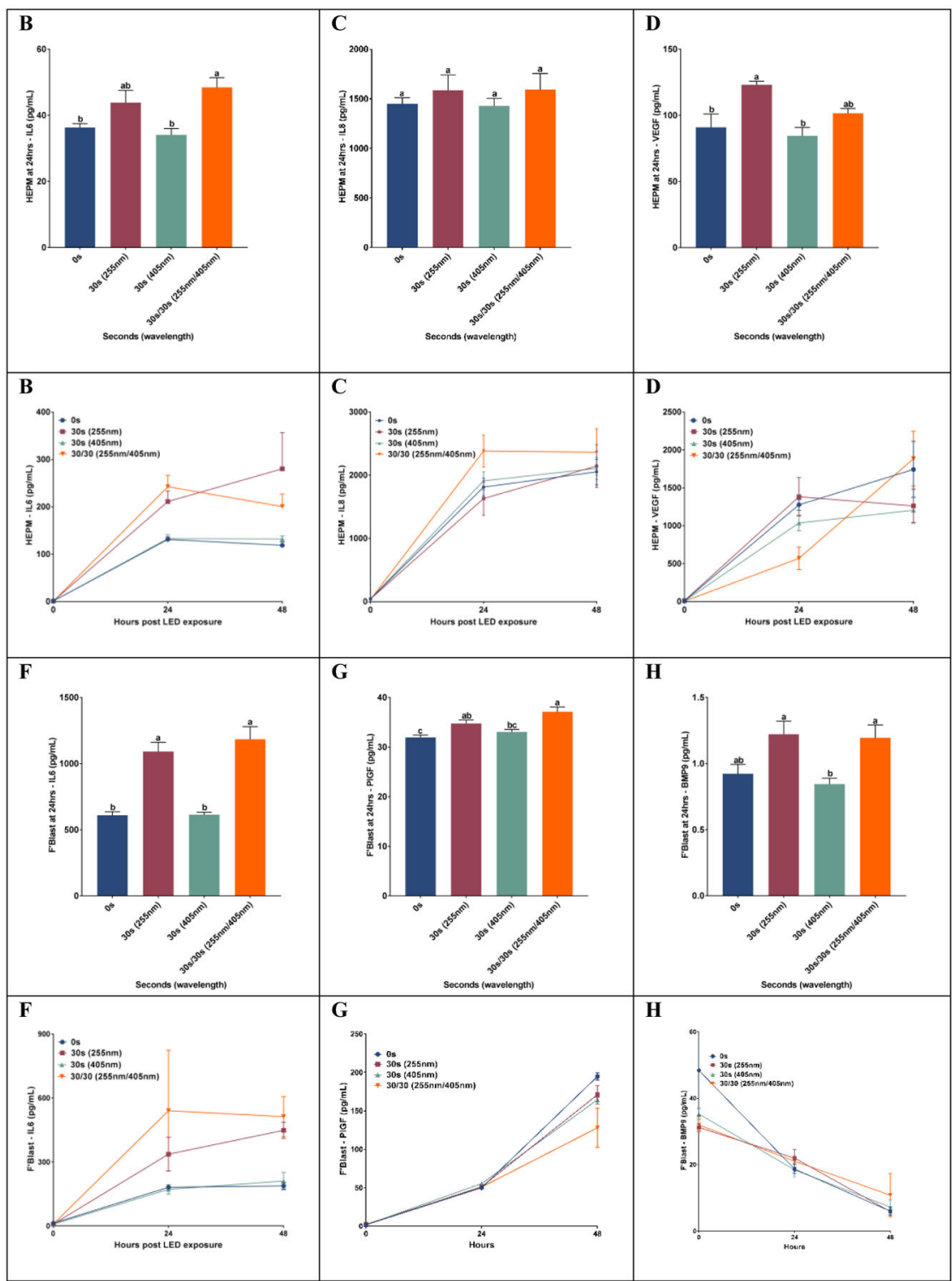

Figure 6.

Experiments assessing the ability of $255 \mathrm{~nm}, 405 \mathrm{~nm}$, and $255 \mathrm{~nm} / 405 \mathrm{~nm}$ combination LED exposure to induce the production of HEPM cell biomarkers $(A-F)$ and human fibroblast biomarkers $(G-H)$ at 24 hours and 48 hours post-LED exposure. Bar values with the same letter(s) were not significantly different $(\mathrm{p}>.05)$. 
Table 1.

Mean (Standard error) concentrations $(\mathrm{pg} / \mathrm{mL})$ of biomarkers produced by HEPM cells and human fibroblasts (0 to $48 \mathrm{hrs)}$.

\begin{tabular}{|c|c|c|c|}
\hline Class/Marker & Hours & HEPM cells & Fibroblasts \\
\hline \multicolumn{4}{|c|}{ Osteoinductive factors } \\
\hline \multirow[t]{3}{*}{ BMP-2 } & 0 & $11.47(0.86)$ & $15.50(4.00)$ \\
\hline & 24 & $15.80(0.80)$ & $11.20(0.70)$ \\
\hline & 48 & $18.67(0.81)$ & $12.37(0.77)$ \\
\hline \multirow[t]{3}{*}{ BMP-4 } & 0 & $5.00(1.25)$ & $4.27(4.27)$ \\
\hline & 24 & $8.50(0.92)$ & $10.00(0.30)$ \\
\hline & 48 & $10.07(1.19)$ & $12.50(0.93)$ \\
\hline \multirow[t]{3}{*}{ BMP-9 } & 0 & $27.53(0.27)$ & $48.40(13.81)$ \\
\hline & 24 & $20.17(0.24)$ & $18.67(1.38)$ \\
\hline & 48 & $10.47(2.67)$ & $5.97(1.35)$ \\
\hline \multirow[t]{3}{*}{ BMP-10 } & 0 & $307.23(11.28)$ & 527.57 (187.67) \\
\hline & 24 & $262.57(1.73)$ & $261.57(6.53)$ \\
\hline & 48 & $227.83(13.74)$ & $184.07(25.59)$ \\
\hline \multicolumn{4}{|c|}{ Angiogenic factors } \\
\hline \multirow[t]{3}{*}{ VEGFA } & 0 & $9.80(0.97)$ & $28.70(7.89)$ \\
\hline & 24 & 1277.67 (71.98) & $1323.67(76.43)$ \\
\hline & 48 & $1744.33(369.08)$ & $3542.00(475.43)$ \\
\hline \multirow[t]{3}{*}{ PDGF-AB } & 0 & $1.77(0.53)$ & $8.33(4.66)$ \\
\hline & 24 & $7.03(0.44)$ & $8.33(1.45)$ \\
\hline & 48 & $5.70(0.29)$ & $7.20(1.16)$ \\
\hline \multirow[t]{3}{*}{ FGF (acidic) } & 0 & $75.53(2.95)$ & $67.20(2.39)$ \\
\hline & 24 & $66.77(4.27)$ & $59.30(7.48)$ \\
\hline & 48 & $56.27(2.77)$ & $45.03(1.09)$ \\
\hline \multirow[t]{3}{*}{ PIGF } & 0 & $1.20(0.20)$ & $1.80(0.06)$ \\
\hline & 24 & $26.33(1.18)$ & $50.03(1.78)$ \\
\hline & 48 & $90.73(3.29)$ & $194.80(5.04)$ \\
\hline \multicolumn{4}{|c|}{ Proliferation factors } \\
\hline \multirow[t]{3}{*}{ EGF } & 0 & $2.30(0.06)$ & $2.73(0.53)$ \\
\hline & 24 & $2.40(0.06)$ & $2.43(0.03)$ \\
\hline & 48 & $2.40(0.06)$ & $2.37(0.03)$ \\
\hline \multirow[t]{3}{*}{ TGFa } & 0 & $1.03(0.03)$ & $1.50(0.40)$ \\
\hline & 24 & $1.03(0.03)$ & $1.13(0.09)$ \\
\hline & 48 & $1.07(0.15)$ & $1.37(0.03)$ \\
\hline \multicolumn{4}{|c|}{ Proinflammatory factors } \\
\hline \multirow[t]{2}{*}{ IL-6 } & 0 & $1.17(0.15)$ & $13.13(1.07)$ \\
\hline & 24 & $131.33(5.31)$ & $181.17(8.17)$ \\
\hline
\end{tabular}

JEndod. Author manuscript; available in PMC 2020 June 01. 


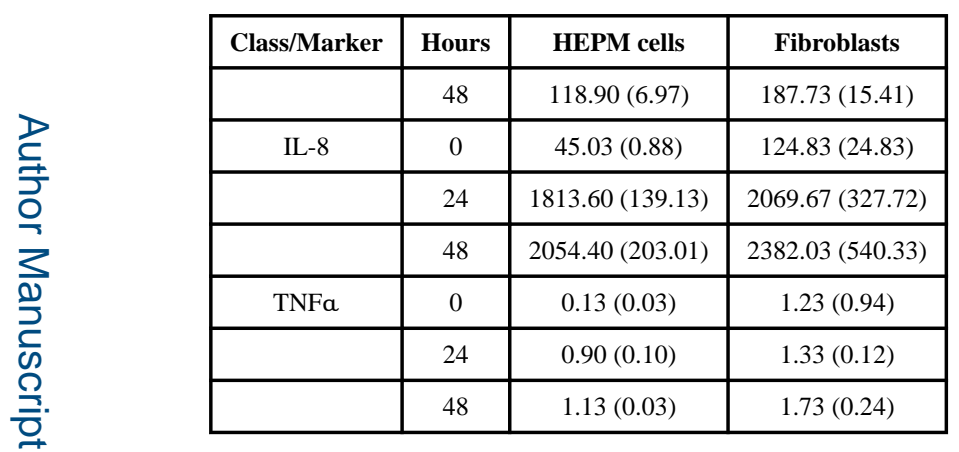

